\title{
PENYAKIT PRIORITAS DI KABUPATEN BADUNG
}

\author{
Sugianto, Made Agus \\ Badan Penelitian dan Pengembangan Kabupaten Badung \\ Korespondensi: agussugianto146@gmail.com
}

\begin{abstract}
Background: The Central Government and Local Governments including Badung Regency are facing the burden of communicable and non-communicable diseases which has not ended until now. Purpose: to find out the most priority diseases to be prevented and controlled in Badung Regency. Methods: This is a descriptiveanalytic study using secondary data from monthly reports of outpatient visits and inpatients at the health center and the Mangusada Regional Hospital during 2014 2018. Besides, interviews were also conducted with respondents with a health education background. Results: The scoring results show Hypertension as the first ranked disease to be treated in Badung Regency with a score of 63.8. This disease is classified as a non-communicable disease group. The disease that is ranked second is HIV / AIDS which is an infectious disease with a score of 58.9, and the third rank is occupied by Diabetes Mellitus, which is also a non-communicable disease with a score of 58.7. Conclusion: Based on the results of the interview, hypertension is the most priority disease to be tackled in Badung Regency in 2019. The second and third priority diseases are respectively occupied by HIV / AIDS and Diabetes Mellitus.
\end{abstract}

Keywords: Badung regency; Infectious diseases; Non-communicable diseases

\begin{abstract}
ABSTRAK
Latar belakang: Pemerintah Pusat maupun Pemerintah Daerah termasuk Kabupaten Badung menghadapi beban penyakit menular dan penyakit tidak menular yang tidak kunjung usai sampai dengan saat ini. Tujuan: untuk mengetahui penyakit yang paling prioritas untuk dicegah dan dikendalikan di Kabupaten Badung. Metode: adalah penelitian deskriptif analitik menggunakan data sekunder laporan bulanan kunjungan pasien jalan dan pasien rawat inap di puskesmas serta RS Daerah Mangusada sepanjang tahun 2014 - 2018. Selain itu, juga dilakukan wawancara kepada responden dengan latar belakang pendidikan kesehatan. Hasil: Hasil scoring menunjukan Hipertensi sebagai penyakit ranking pertama untuk ditangani di Kabupaten Badung dengan nilai score 63,8. Penyakit ini tergolong dalam kelompok penyakit tidak menular. Penyakit yang menduduki ranking kedua adalah HIV/AIDS yang merupakan penyakit menular dengan nilai score 58,9, dan ranking ketiga diduduki oleh penyakit Diabetes Melitus yang juga penyakit tidak menular dengan nilai score 58,7. Simpulan: Hipertensi merupakan penyakit yang paling prioritas untuk ditanggulangi di Kabupaten Badung pada tahun 2019. Penyakit kedua dan ketiga yang menjadi prioritas masing-masing ditempati oleh penyakit HIV/AIDS dan Diabetes Melitus.
\end{abstract}


Kata kunci: Kabupaten Badung; Penyakit menular; Penyakit tidak menular

\section{PENDAHULUAN}

Visi dan Misi Bupati Badung yang tertuang dalam Rencana Pembangunan Jangka Menengah Daerah (RPJMD) Semesta Berencana tahun 2016-2021, memprioritaskan pembangunan bidang kesehatan sebagai upaya peningkatan kualitas SDM dan menurunkan angka kemiskinan di Kabupaten Badung. Untuk mengoptimalkan pencapaian pembangunan kesehatan di Kabupaten Badung, Dinas Kesehatan Kebupaten Badung telah menyusun beberapa program penting yang bertujuan untuk menurunkan angka kesakitan dan kematian di Kabupaten Badung. Salah satu program tersebut adalah Program Pencegahan dan Penanggulangan Penyakit Menular dan Penyakit Tidak Menular (Dinkes Kab.Badung, 2017).

Menurut Surya Darmawan (2016), Penyakit Menular (PM) merupakan penyakit infeksi yang disebabkan oleh mikroorganisme, seperti virus, bakteri, parasit atau jamur, dan dapat berpindah ke orang lain yang sehat, sedangkan Penyakit Tidak Menular (TPM) adalah jenis penyakit yang tidak menular seperti cacat fisik, gangguan mental, kanker, penyakit degeneratif, penyakit gangguan metabolisme, dan kelainan-kelainan organ tubuh lainnya seperti : penyakit jantung, pembuluh darah, penyakit tekanan darah tinggi, penyakit kencing manis, berat badan lebih, osteoporosis, kanker usus, depresi dan kecemasan.

Peraturan Menteri Kesehatan RI Nomor 39 Tahun 2016 tentang Pedoman Penyelenggaraan Program Indonesia Sehat Dengan Pendekatan Keluarga, prioritas pencegahan dan penanggulangan penyakit menular masih tertuju pada penyakit HIV/AIDS, menyatakan bahwa Indonesia telah mengalami transisi epidemiologis selama 2 dekade terakhir, yakni penyakit tidak menular telah menjadi beban utama, sementara beban penyakit menular masih berat juga. Penyakit menular yang menjadi prioritas di Indonesia saat ini adalah Tuberkulosis, Malaria, Demam Berdarah, HIV/AIDS, Influenza dan Flu Burung, sedangkan penyakit tidak menular utama meliputi Hipertensi, Diabetes Melitus, Kanker dan Penyakit Paru Obstruktif Kronik (PPOK), (Kemenkes RI, 2016).

Menurut Profil Dinas Kesehatan Provinsi Bali Tahun 2017, penyakit terbanyak di Provinsi Bali masih didominasi oleh penyakit menular seperti : DBD 
(4.487 kasus) dan TBC (3.499 kasus), penyakit tersebut banyak ditemukan di Kota Denpasar dan Kabupaten Badung. Berdasarkan laporan Sistem Pencatatan dan Pelaporan Terpadu Puskesmas (SP2TP), data $e$-Puskesmas dan laporan kunjungan pasien rawat jalan serta rawat inap di RS Daerah Mangusada, beberapa penyakit menular yang dominan menyerang penduduk antara lain: penyakit Infeksi Saluran Pernafasan Akut (ISPA), Demam Berdarah Dengue (DBD) dan Pneumonia, sedangkan untuk penyakit tidak menular di dominasi oleh penyakit Hipertensi dan Diabetes Mellitus (DM) type II.

\section{TUJUAN}

Secara umum penelitian ini bertujuan untuk mengetahui penyakit yang paling prioritas untuk dicegah dan dikendalikan di Kabupaten Badung.

\section{METODE PENELITIAN}

Penelitian ini adalah penelitian deskriptif analitik. Penelitian ini dilaksanakan di Kabupaten Badung selama dua bulan yaitu dari bulan Juni - Juli 2019. Data sekunder dalam penelitian ini adalah laporan bulanan pasien rawat jalan di puskesmas, pasien rawat jalan dan pasien rawat inap di RS Daerah Mangusada sepanjang tahun 2014 - 2018. Penentuan penyakit prioritas di lakukan dengan sistem scoring. Nilai score diperolah dari hasil wawancara kepada responden dengan latar belakang pendidikan kesehatan.

\section{HASIL}

Langkah pertama dalam menentukan prioritas masalah adalah dengan melakukan identifikasi masalah. Identifikasi masalah dilakukan dengan cara melihat data 10 (sepuluh) besar penyakit kunjungan pasien rawat jalan puskesmas, kunjungan rawat jalan dan rawat inap pasien Rumah Sakit (RS) Daerah Mangusada periode tahun 2014 sampai dengan 2018. Dari data kunjungan pasien tersebut dipilih beberapa penyakit yang masuk dalam 3 (tiga) besar penyakit terbanyak. Langkah selanjutnya menentukan satu penyakit yang menjadi prioritas untuk ditanggulangi dengan menggunakan metode Scoring. 
Berdasarkan laporan Sistem Pencatatan dan Pelaporan Terpadu Puskesmas (SP2TP) dan data e-Puskesmas diperoleh 10 (sepuluh) besar penyakit di Kabupaten Badung seperti pada Table.1. Pada Tabel 1 terlihat bahwa hipertensi merupakan penyakit rawat jalan terbanyak di puskesmas sepanjang tahun 2014 s.d 2018, penyakit ini tergolong dalam kelompok penyakit tidak menular. Penyakit terbanyak berikutnya adalah Infeksi Saluran Pernafasan Akut (ISPA), Faringitis Akut dan Nasoparingitis Akut. Penyakit Faringitis Akut dan Nasoparingitis Akut termasuk dalam rumpun penyakit ISPA, dan penyakit ini termasuk dalam kategori penyakit menular.

Tabel 1. Sepuluh Besar Penyakit Kunjungan Rawat Jalan Puskesmas Tahun 2014 Sampai Dengan 2018

\begin{tabular}{|c|c|c|c|c|c|c|c|c|c|c|}
\hline \multirow[b]{2}{*}{ No } & \multicolumn{2}{|c|}{ Tahun 2014} & \multicolumn{2}{|c|}{ Tahun 2015} & \multicolumn{2}{|c|}{ Tahun 2016} & \multicolumn{2}{|c|}{ Tahun 2017} & \multicolumn{2}{|c|}{ Tahun 2018} \\
\hline & Penyakit & $\begin{array}{c}\text { Jumlah } \\
\text { Kasus }\end{array}$ & Penyakit & $\begin{array}{l}\text { Jumlah } \\
\text { Kasus }\end{array}$ & Penyakit & $\begin{array}{c}\text { Jumlah } \\
\text { Kasus }\end{array}$ & Penyakit & $\begin{array}{c}\text { Jumlah } \\
\text { Kasus }\end{array}$ & Penyakit & $\begin{array}{c}\text { Jumlah } \\
\text { Kasus }\end{array}$ \\
\hline 1 & Demam & 9.074 & Hipertensi & 10.865 & Demam & 12.674 & Hipertensi & 8.819 & Hipertensi & 10.274 \\
\hline 2 & $\begin{array}{l}\text { Faringitis } \\
\text { Akut }\end{array}$ & 7.018 & Demam & 10.167 & Hipertensi & 9.933 & $\begin{array}{l}\text { Inf.Sal. Nafas } \\
\text { Akut }\end{array}$ & 8.407 & $\begin{array}{l}\text { Inf.Sal. Nafas } \\
\text { Akut }\end{array}$ & 6.727 \\
\hline 3 & Hipertensi & 6.625 & $\begin{array}{l}\text { Nasoparingitis } \\
\text { Akut }\end{array}$ & 9.052 & $\begin{array}{l}\text { Faringitis } \\
\text { Akut }\end{array}$ & 8.758 & $\begin{array}{l}\text { Faringitis } \\
\text { Akut }\end{array}$ & 5.851 & $\begin{array}{l}\text { Nasoparingitis } \\
\text { Akut }\end{array}$ & 4.718 \\
\hline 4 & $\begin{array}{l}\text { Nasoparingitis } \\
\text { Akut }\end{array}$ & 6.452 & $\begin{array}{l}\text { Faringitis } \\
\text { Akut }\end{array}$ & 8.430 & $\begin{array}{l}\text { Nasoparingitis } \\
\text { Akut }\end{array}$ & 8.385 & Demam & 4.656 & $\begin{array}{l}\text { Faringitis } \\
\text { Akut }\end{array}$ & 3.995 \\
\hline 5 & $\begin{array}{l}\text { Gigitan } \\
\text { Anjing }\end{array}$ & 6.020 & $\begin{array}{l}\text { Dermatitis } \\
\text { Alergi }\end{array}$ & 5.324 & $\begin{array}{l}\text { Diabetes } \\
\text { Melitus }\end{array}$ & 5.677 & $\begin{array}{l}\text { Nasoparingitis } \\
\text { Akut }\end{array}$ & 3.596 & Demam & 2.737 \\
\hline 6 & $\begin{array}{l}\text { Dermatitis } \\
\text { Alergi }\end{array}$ & 4.205 & Myalgia & 5.149 & $\begin{array}{l}\text { Dermatitis } \\
\text { Alergi }\end{array}$ & 5.082 & $\begin{array}{l}\text { Necrosis Of } \\
\text { Pulp }\end{array}$ & 2.202 & Imunisasi & 2.542 \\
\hline 7 & $\begin{array}{l}\text { Cepalgia } \\
\text { (Sakit Kepala) }\end{array}$ & 3.926 & $\begin{array}{l}\text { Diabetes } \\
\text { Melitus }\end{array}$ & 4.590 & $\begin{array}{l}\text { Cepalgia } \\
\text { (Sakit Kepala) }\end{array}$ & 5.034 & $\begin{array}{l}\text { Gangguan } \\
\text { Mental }\end{array}$ & 1.907 & Luka Terbuka & 2.468 \\
\hline 8 & Artritis & 3.515 & Artritis & 4.506 & $\begin{array}{l}\text { Diare (Gastro } \\
\text { Enteritis) }\end{array}$ & 4.009 & Luka Terbuka & 1.904 & $\begin{array}{l}\text { Gangguan } \\
\text { Mental }\end{array}$ & 2.009 \\
\hline 11 & $\begin{array}{l}\text { Diare (Gastro } \\
\text { Enteritis) }\end{array}$ & 3.147 & $\begin{array}{l}\text { Diare (Gastro } \\
\text { Enteritis) }\end{array}$ & 3.915 & Myalgia & 3.673 & $\begin{array}{l}\text { Gigitan } \\
\text { Anjing }\end{array}$ & 1.573 & $\begin{array}{l}\text { Necrosis Of } \\
\text { Pulp }\end{array}$ & 1.838 \\
\hline
\end{tabular}

Sumber: Laporan SP2TP Puskesmas dan data e-Puskesmas Tahun 2014 sampai dengan 2018 
Tabel 2. Sepuluh Besar Penyakit Kunjungan Rawat Jalan RS Daerah Mangusada Tahun 2014 Sampai Dengan 2018

\begin{tabular}{|c|c|c|c|c|c|c|c|c|c|c|}
\hline \multirow[b]{2}{*}{ No } & \multicolumn{2}{|c|}{ Tahun 2014} & \multicolumn{2}{|c|}{ Tahun 2015} & \multicolumn{2}{|c|}{ Tahun 2016} & \multicolumn{2}{|c|}{ Tahun 2017} & \multicolumn{2}{|c|}{ Tahun 2018} \\
\hline & Penyakit & $\begin{array}{l}\text { Jumlah } \\
\text { Kasus }\end{array}$ & Penyakit & $\begin{array}{l}\text { Jumlah } \\
\text { Kasus }\end{array}$ & Penyakit & $\begin{array}{c}\text { Jumlah } \\
\text { Kasus }\end{array}$ & Penyakit & $\begin{array}{l}\text { Jumlah } \\
\text { Kasus }\end{array}$ & Penyakit & $\begin{array}{c}\text { Jumlah } \\
\text { Kasus }\end{array}$ \\
\hline 1 & Demam & 7.674 & Demam & 5.167 & $\begin{array}{l}\text { Diabetes } \\
\text { Melitus }\end{array}$ & 7.754 & $\begin{array}{l}\text { Diabetes } \\
\text { Melitus }\end{array}$ & 9.724 & $\begin{array}{l}\text { Diabetes } \\
\text { Melitus }\end{array}$ & 10.160 \\
\hline 2 & $\begin{array}{l}\text { Diabetes } \\
\text { Melitus }\end{array}$ & 4.157 & $\begin{array}{l}\text { Diabetes } \\
\text { Melitus }\end{array}$ & 2.836 & DBD & 3.532 & Hipertensi & 6.612 & Hipertensi & 7.564 \\
\hline 3 & Glomerolus & 3.551 & DBD & 2.475 & Hipertensi & 2.712 & $\begin{array}{l}\text { Kelainan Pd } \\
\text { Mata }\end{array}$ & 3.213 & $\begin{array}{l}\text { Penyumbatan } \\
\text { Arteri Otak }\end{array}$ & 4.746 \\
\hline 4 & $\begin{array}{l}\text { Luka Pd } \\
\text { Kaki }\end{array}$ & 3.401 & Infeksi Otak & 2.423 & Epilepsi & 2.356 & Katarak & 3.163 & $\begin{array}{l}\text { Sakit Tulang } \\
\text { Belakang }\end{array}$ & 3.903 \\
\hline 5 & Hiv & 3.318 & Epilepsi & 1.843 & Demam & 1.780 & $\begin{array}{l}\text { Gang. Pada } \\
\text { Otak }\end{array}$ & 3.142 & $\begin{array}{l}\text { Nepritik } \\
\text { Kronis }\end{array}$ & 3.867 \\
\hline 6 & Hipertensi & 2.773 & Asma & 1.800 & $\begin{array}{l}\text { Gangguan } \\
\text { Jantung }\end{array}$ & 1.780 & $\begin{array}{l}\text { Hipersensitif } \\
\text { Pd Jantung }\end{array}$ & 2.702 & Epilepsi & 3.144 \\
\hline 7 & $\mathrm{DBD}$ & 2.429 & Hipertensi & 1.543 & $\mathrm{DBD}$ & 1.752 & $\begin{array}{l}\text { Nepritik } \\
\text { Kronis }\end{array}$ & 2.577 & Katarak & 3.129 \\
\hline 8 & Asma & 2.429 & $\begin{array}{l}\text { Luka Pd } \\
\text { Kaki }\end{array}$ & 1.511 & $\begin{array}{l}\text { Nepritik } \\
\text { Kronis }\end{array}$ & 1.504 & $\begin{array}{l}\text { Perawatan } \\
\text { Medis }\end{array}$ & 2.576 & $\begin{array}{l}\text { Kelainan Pd } \\
\text { Mata }\end{array}$ & 3.058 \\
\hline 9 & $\begin{array}{l}\text { Nyeri } \\
\text { Kembung }\end{array}$ & 1.865 & $\begin{array}{l}\text { Gagal } \\
\text { Jantung }\end{array}$ & 1.490 & $\begin{array}{l}\text { Kelainan Pd } \\
\text { Mata }\end{array}$ & 1.480 & $\begin{array}{l}\text { Sakit Tulang } \\
\text { Belakang }\end{array}$ & 2.491 & Athrosklerosis & 2.953 \\
\hline 10 & Patah Tulang & 1.629 & $\begin{array}{l}\text { Luka Pd } \\
\text { Persendian }\end{array}$ & 1.291 & $\begin{array}{l}\text { Infeksi } \\
\text { Tyroid }\end{array}$ & 1.453 & $\begin{array}{l}\text { Gang. Arteri } \\
\text { Jantung }\end{array}$ & 2.354 & Dispepsia & 2.953 \\
\hline
\end{tabular}

Sumber: Laporan Kunjungan Rawat Jalan RSD Mangusada Tahun 2014 sampai dengan 2018

Pada Tabel 2 terlihat bahwa Diabetes Melitus menempati urutan pertama kasus terbanyak pasien rawat jalan di RS Daerah Mangusada sepanjang tahun 20142018, diikuti oleh Hipertensi dan DBD. DBD termasuk kategori penyakit menular, sedangkan yang tergolong penyakit tidak menular adalah Diabetes Melitus dan Hipertensi.

Kunjungan rawat inap di RS Daerah Mangusada didominasi oleh penyakit menular DBD dan pneumonia, serta penyakit tidak menular penyumbatan pembuluh darah otak. Untuk lebih jelasnya dapat dilihat pada Tabel 3. 
Tabel 3. Sepuluh Besar Penyakit Kunjungan Rawat Inap RS Daerah Mangusada Tahun 2014 Sampai Dengan 2018

\begin{tabular}{|c|c|c|c|c|c|c|c|c|c|c|}
\hline \multirow[b]{2}{*}{ No } & \multicolumn{2}{|c|}{ Tahun 2014} & \multicolumn{2}{|c|}{ Tahun 2015} & \multicolumn{2}{|c|}{ Tahun 2016} & \multicolumn{2}{|c|}{ Tahun 2017} & \multicolumn{2}{|c|}{ Tahun 2018} \\
\hline & Penyakit & $\begin{array}{c}\text { Jumlah } \\
\text { Kasus }\end{array}$ & Penyakit & $\begin{array}{c}\text { Jumlah } \\
\text { Kasus }\end{array}$ & Penyakit & $\begin{array}{l}\text { Jumlah } \\
\text { Kasus }\end{array}$ & Penyakit & $\begin{array}{l}\text { Jumlah } \\
\text { Kasus }\end{array}$ & Penyakit & $\begin{array}{c}\text { Jumlah } \\
\text { Kasus }\end{array}$ \\
\hline 1 & DBD & 1.082 & DBD & 1.498 & DBD & 2.509 & Pneumonia & 1.028 & Pneumonia & 759 \\
\hline 2 & $\begin{array}{l}\text { Penyumbatan } \\
\text { Arteri Otak }\end{array}$ & 228 & $\begin{array}{l}\text { Penyumbatan } \\
\text { Arteri Otak }\end{array}$ & 292 & $\begin{array}{l}\text { Penyumbatan } \\
\text { Arteri Otak }\end{array}$ & 359 & $\begin{array}{l}\text { Melahirkan } \\
\text { Normal }\end{array}$ & 1.020 & Gegar Otak & 444 \\
\hline 3 & Pneumonia & 166 & $\begin{array}{l}\text { Diabetes } \\
\text { Melitus }\end{array}$ & 256 & Neoplasma & 330 & $\begin{array}{l}\text { Melahirkan } \\
\text { Cesar }\end{array}$ & 717 & $\begin{array}{l}\text { Penyumbatan } \\
\text { Arteri Otak }\end{array}$ & 298 \\
\hline 4 & Hernia & 152 & Pneumonia & 216 & $\begin{array}{l}\text { Diabetes } \\
\text { Melitus }\end{array}$ & 211 & DBD & 672 & Diare (Ge) & 271 \\
\hline 5 & Diare $(\mathrm{Ge})$ & 150 & Demam & 197 & Hernia & 208 & Hernia & 586 & Neoplasma & 270 \\
\hline 6 & Demam & 150 & Hernia & 180 & $\begin{array}{l}\text { Gagal } \\
\text { Jantung }\end{array}$ & 199 & Anemia & 564 & $\begin{array}{l}\text { Gagal } \\
\text { Jantung }\end{array}$ & 244 \\
\hline 7 & $\begin{array}{l}\text { Appendik } \\
\text { Akut }\end{array}$ & 148 & $\begin{array}{l}\text { Appendik } \\
\text { Akut }\end{array}$ & 169 & Gegar Otak & 191 & $\begin{array}{l}\text { Diabetes } \\
\text { Melitus }\end{array}$ & 545 & $\begin{array}{l}\text { Appendik } \\
\text { Akut }\end{array}$ & 226 \\
\hline 8 & $\begin{array}{l}\text { Diabetes } \\
\text { Melitus }\end{array}$ & 125 & Neoplasma & 158 & Diare (Ge) & 190 & $\begin{array}{l}\text { Penyumbatan } \\
\text { Arteri Otak }\end{array}$ & 468 & $\begin{array}{l}\text { Diabetes } \\
\text { Melitus }\end{array}$ & 215 \\
\hline 9 & $\begin{array}{l}\text { Tonsilitis } \\
\text { Kronis }\end{array}$ & 106 & Diare (Ge) & 149 & $\begin{array}{l}\text { Appendik } \\
\text { Akut }\end{array}$ & 176 & $\begin{array}{l}\text { Gagal } \\
\text { Jantung }\end{array}$ & 399 & Anemia & 182 \\
\hline 10 & Gegar Otak & 101 & Hipertensi & 137 & Pneumonia & 160 & Neoplasma & 305 & $\begin{array}{l}\text { Gagal Ginjal } \\
\text { Kronis }\end{array}$ & 168 \\
\hline
\end{tabular}

Sumber: Laporan Kunjungan Rawat Inap RSD Mangusada Tahun 2014 sampai dengan 2018

Berdasarkan identifikasi masalah di atas, maka penyakit menular yang masuk dalam skala prioritas untuk ditanggulangi di Kabupaten Badung antara lain; penyakit ISPA, Pneumonia dan DBD, sedangkan untuk penyakit tidak menular Hipertensi dan Diabetes Melitus. Di samping itu, berdasarkan hasil wawancara dengan pengelola program HIV/AIDS dan Tuberkulosis (TB Paru), responden menyatakan bahwa penyakit HIV/AIDS dan TB Paru pada tahun 2018 belum mencapi target penemuan penderita sesuai target yang ditetapkan. Demikian pula dengan Renstra Kementerian Kesehatan RI Tahun 2015-2019 memprioritaskan kedua penyakit ini untuk mendapatkan penanganan. Berkaitan dengan itu, maka HIV/AIDS dan TB Paru juga dimasukan dalam skala prioritas penyakit yang ada di Kabupaten Badung.

Penentuan penyakit prioritas dilakukan menggunakan metode scoring, yaitu memberikan score antara 1 - 10 yang melibatkan beberapa responden. Pemilihan responden dilakukan dengan menggunakan teknik sampling secara purposive. Hasil sampling diperoleh sebanyak 51 responden yang terdiri dari akademisi, petugas Dinas Kesehatan Provinsi Bali, Dinas Kesehatan Kabupaten/Kota, Puskesmas Kabupaten/Kota, RS negeri dan swasta, yang memiliki pengalaman dan 
kemampuan akademis cukup baik (minimal D III) di bidang kesehatan.

Karakteristik responden dapat dilihat pada beberapa tabel di bawah ini.

Tabel 4. Karakteristik Responden Berdasarkan Kelompok Umur dan Jenis Kelamin

\begin{tabular}{|c|c|c|c|c|c|c|}
\hline \multirow{2}{*}{ No } & \multirow{2}{*}{$\begin{array}{c}\text { Jenis } \\
\text { Kelamin }\end{array}$} & \multicolumn{4}{|c|}{ Kelompok Umur (Tahun) } & \multirow[t]{2}{*}{ Jumlah } \\
\hline & & $20-30$ & $31-40$ & $41-50$ & $>50$ & \\
\hline 1 & Laki-Laki & 5 & 3 & 2 & 1 & 11 \\
\hline 2 & Perempuan & 16 & 17 & 5 & 2 & 40 \\
\hline & Total & 21 & 20 & 7 & 3 & 51 \\
\hline
\end{tabular}

Tabel 4 menunjukan bahwa mayoritas responden berjenis kelamin perempuan yaitu sebanyak 40 orang $(78,43 \%)$, sedangkan yang berjenis kelamin laki-laki hanya 11 orang $(21,57 \%)$. Untuk kelompok umur responden terbanyak berusia antara 20-30 tahun yaitu sebanyak 21 orang $(41,17 \%)$, dan yang paling sedikit berusia di atas 50 tahun yaitu sebanyak 3 orang $(5,88 \%)$.

Tabel 5. Karakteristik Responden Berdasarkan Institusi Tempat Bekerja dan Tingkat Pendidikan

\begin{tabular}{|c|c|c|c|c|c|c|c|c|c|c|c|c|}
\hline \multirow[b]{2}{*}{ No } & \multirow[b]{2}{*}{ Institusi } & \multicolumn{10}{|c|}{ Jenis Pendidikan } & \multirow[b]{2}{*}{ Jumlah } \\
\hline & & $\begin{array}{l}\text { DIII } \\
\text { Bidan }\end{array}$ & $\begin{array}{c}\text { DIII } \\
\text { Elektro } \\
\text { Medik }\end{array}$ & $\begin{array}{l}\text { DIII } \\
\text { Gizi }\end{array}$ & $\begin{array}{c}\text { DIII } \\
\text { Kesling }\end{array}$ & $\begin{array}{c}\text { DIII } \\
\text { Perawat }\end{array}$ & $\begin{array}{c}\text { DIII } \\
\text { Perawatan }\end{array}$ & $\begin{array}{c}\text { S1 } \\
\text { Dokter } \\
\text { Gigi }\end{array}$ & $\begin{array}{c}\text { S1 } \\
\text { Dokter } \\
\text { Umum }\end{array}$ & $\begin{array}{c}\text { S1 } \\
\text { Kes.Masya } \\
\text { rakat }\end{array}$ & $\begin{array}{c}\text { S2 } \\
\text { Kes.Masya } \\
\text { rakat }\end{array}$ & \\
\hline 1 & $\begin{array}{l}\text { Perguruan } \\
\text { Tinggi }\end{array}$ & - & - & - & - & - & - & - & - & 2 & 2 & 4 \\
\hline 2 & $\begin{array}{l}\text { Dinkes Prov. } \\
\text { Bali }\end{array}$ & 2 & - & - & - & 1 & - & - & - & 1 & 1 & 5 \\
\hline 3 & $\begin{array}{l}\text { Dinkes } \\
\text { Kabupaten/Kota }\end{array}$ & 4 & - & 1 & 2 & - & - & - & - & 2 & 1 & 10 \\
\hline 4 & Rumah Sakit & 2 & - & - & 2 & - & - & - & - & 4 & 1 & 9 \\
\hline 5 & Puskesmas & 6 & - & - & - & - & 1 & 1 & 4 & 1 & - & 13 \\
\hline \multirow[t]{2}{*}{6} & Lainnya & 4 & 1 & & 5 & - & - & - & - & - & - & 10 \\
\hline & Total & 18 & 1 & 1 & 9 & 1 & 1 & 1 & 4 & 10 & 5 & 51 \\
\hline
\end{tabular}

Pada tabel 5 terlihat bahwa mayoritas responden memiliki tingkat pendidikan DIII Kebidanan yaitu sebanyak 18 orang $(35,29 \%)$ dan yang paling sedikit tingkat pendidikan DIII Elektro Medik, DIII Gizi, DIII Keperawatan dan Kedokteran Gigi yaitu masing-masing sebanyak 1 orang $(1,96 \%)$.

Untuk mendapatkan hasil yang obyektif, dalam memberikan score responden mempertimbangkan beberapa aspek sebagai berikut : 1) Besar masalah : jumlah kasus atau angka kesakitan yang ditimbulkan akibat penyakit tersebut. 2) Kemudahan penanggulangan : ketersediaan Sumber Daya Manusia (SDM), 
ketersediaan obat, peralatan dan teknologi penyembuhan. 3) Beban kematian : angka kematian yang ditimbulkan akibat penyakit tersebut. 4) Kematian usia muda : kematian usia muda yang ditimbulkan akibat penyakit tersebut. 5) Kehilangan produktivitas : penurunan kemampuan beraktivitas akibat adanya penyakit tersebut. 6) Dampak Sosial : dampak dari adanya penyakit terhadap kehidupan sosial masyarakat (mobilitas penduduk, kepanikan, kejadian luar biasa dan stigma). 7) Beban biaya perawatan tinggi : beban biaya perawatan akibat terkena penyakit tersebut. 8) Dampak ekonomi masyarakat yang tinggi : dampak dari adanya penyakit terhadap perekonomian masyarakat.

Hasil rekapitulasi dari beberapa aspek di atas, diperoleh total score seperti terlihat pada Tabel 6 di bawah ini.

Tabel 6. Rekapitulasi Hasil Scoring Penentuan Prioritas Penyakit Menular dan Penyakit Tidak Menular di Kabupaten Badung Tahun 2019

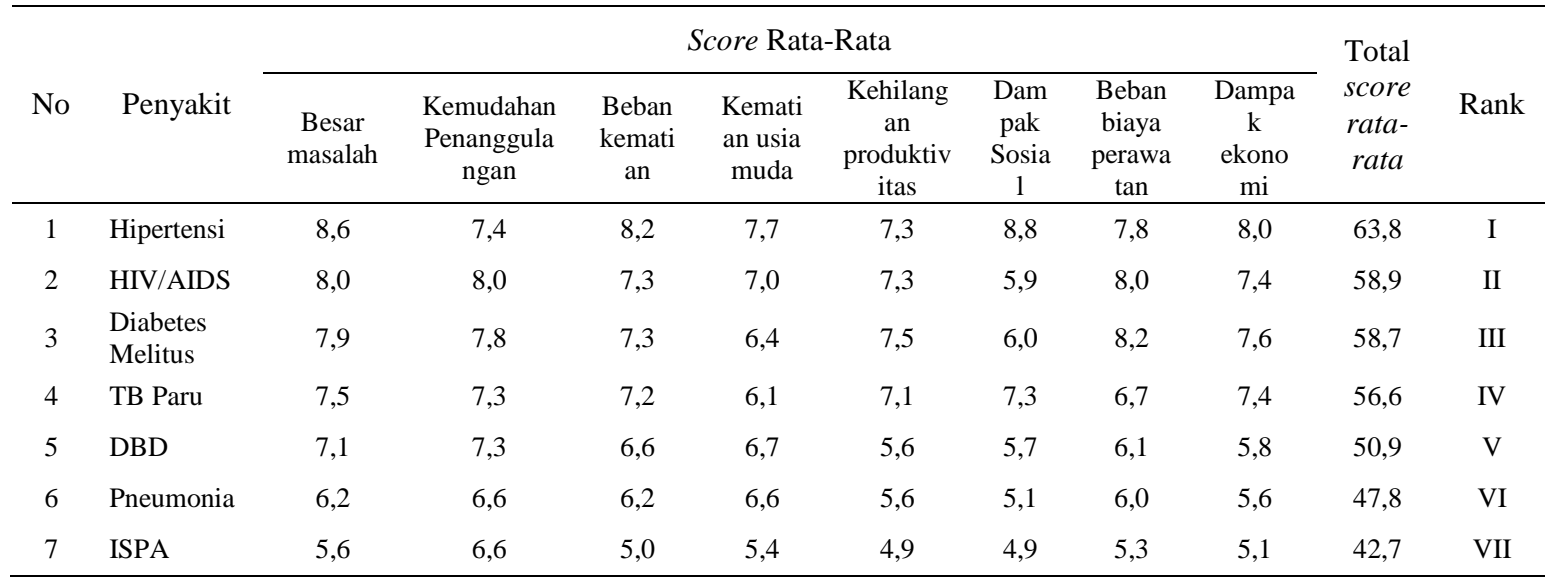

Dari Table 6 dapat disimpulkan bahwa Hipertensi merupakan penyakit yang paling prioritas untuk ditanggulangi di Kabupaten Badung pada tahun 2019. Penyakit kedua dan ketiga yang menjadi prioritas masing-masing adalah penyakit HIV/AIDS dan Diabetes Melitus.

\section{PEMBAHASAN}

Penyakit jantung dan pembuluh darah (kardiovaskuler) merupakan masalah kesehatan utama di negara maju maupun negara berkembang. Hipertensi menjadi penyebab kematian nomor satu di dunia setiap tahunnya. Hipertensi merupakan salah satu pintu masuk atau faktor risiko penyakit seperti jantung, gagal ginjal, diabetes, stroke. Kenaikan prevalensi penyakit Hipertensi berhubungan erat dengan 
pola hidup seperti merokok, konsumsi minuman beralkohol, aktivitas fisik, serta konsumsi buah dan sayur (Kemenkes RI, 2018).

Hipertensi adalah peningkatan tekanan darah sistolik >140 $\mathrm{mmHg}$ dan tekanan darah diastolic $>90 \mathrm{mmHg}$, pada dua kali pengukuran dengan selang waktu lima menit dalam keadaan cukup istirahat/tenang. Hipertensi merupakan faktor risiko dari berbagai penyakit tidak menular lainnya seperti stroke dan penyakit kardiovaskuler. Hipertensi merupakan silent killer, karena gejalanya dapat bervariasi pada masing-masing individu (Mardalena, 2017).

Berdasarkan Riskesdas 2018 prevalensi Hipertensi pada penduduk usia 18 tahun sebesar 34,1\%, tertinggi di Kalimantan Selatan (44.1\%), sedangkan terendah di Papua sebesar (22,2\%). Hipertensi terjadi pada kelompok umur 31-44 tahun $(31,6 \%)$, umur 45-54 tahun (45,3\%), umur 55-64 tahun (55,2\%). Dari prevalensi hipertensi sebesar 34,1\% diketahui bahwa sebesar 8,8\% terdiagnosis hipertensi dan $13,3 \%$ orang yang terdiagnosis hipertensi tidak minum obat serta $32,3 \%$ tidak rutin minum obat. Hal ini menunjukkan bahwa sebagian besar penderita Hipertensi tidak mengetahui bahwa dirinya Hipertensi sehingga tidak mendapatkan pengobatan (Kemenkes RI, 2018).

Penelitian yang dilakukan oleh Louisa, Sulistiyani, \& Joko (2018) menunjukkan bahwa prevalensi hipertensi pada laki-laki lebih banyak lebih besar jika dibandingkan dengan perempuan yaitu sebesar 60\%. Penelitian berbeda dari Setyanda, Sulastri, \& Lestari (2015) menyatakan bahwa ditemukan kebiasaan merokok dan kejadian hipertensi yang banyak ditemukan pada laki-laki yang memiliki usia 35-65 tahun. Demikian pula hasil penelitian yang dilakukan oleh Haryuti, Saraswati, Udiyono, \& Adi (2017) menunjukkan bahwa sebagian responden penelitian berisiko tinggi mengalami penyakit kardiovaskuler. Kondisi tersebut dapat disebabkan data penelitian menyebutkan bahwa yang termasuk dalam kategori obesitas sentral adalah responden dengan rata-rata lingkar perut sebesar 85,40 cm dan dikatakan overweight bila rata-rata status IMT sebesar 27,70 $\mathrm{kg} / \mathrm{m} 2$.

Tingginya kasus Hipertensi tidak hanya terjadi Kabupaten Badung. Berdasarkan data Dinas Kesehatan Kabupaten Tabanan tahun 2018, hipertensi menduduki peringkat pertama 10 besar penyakit di Kabupaten Tabanan dengan 
jumlah kasus mencapai 9.321, dimana 60\% (5.561) penderitanya adalah perempuan sedangkan laki-laki sebanyak 40\% (3.769) (Dinkes Kab. Tabanan, 2018). Demikian pula di Kota Tasikmalaya, berdasarkan data 10 penyakit terbesar yang diperoleh dari Dinas Kesehatan Kota Tasikmalaya Tahun 2018 diperoleh bahwa penyakit hipertensi merupakan penyakit yang memiliki angka kejadian ketiga tertinggi di kota Tasikmalaya yaitu sebesar 23.617. Kemudian didapatkan juga kejadian hipertensi tertinggi terjadi di wilayah kerja Puskesmas Tamansari yaitu sebanyak 2.494 dimana kejadian hipertensi pada laki-laki sebesar 901 dan pada perempuan sebanyak 1.593 (Marini, 2019).

Di Kota Daerah Istimewa Yogyakarta (DIY), Hipertensi selalu masuk dalam 10 besar penyakit sekaligus 10 besar penyebab kematian di DIY selama beberapa tahun terakhir berdasarkan Surveilans Terpadu Penyakit (STP) maupun STP Rumah Sakit. Berdasarkan laporan STP Puskesmas Tahun 2017 tercatat kasus hipertensi sebyanyak 56.668 kasus, sedangkan laporan STP Rumah Sakit Rawat Jalan sebanyak 37.173 kasus (hipertensi esensial) (Riskesdas, 2018).

Untuk mengelola penyakit hipertensi termasuk penyakit tidak menular lainnya, Kementerian Kesehatan RI membuat kebijakan yaitu: 1) Mengembangkan dan memperkuat kegiatan deteksi dini hipertensi secara aktif (skrining). 2) Meningkatkan akses masyarakat terhadap pelayanan deteksi dini melalui kegiatan Posbindu PTM. 3) Meningkatkan akses penderita terhadap pengobatan hipertensi melalui revitalisasi Puskesmas untuk pengendalian PTM melalui Peningkatan sumberdaya tenaga kesehatan yang profesional dan kompenten dalam upaya pengendalian PTM khususnya tatalaksana PTM di fasilitas pelayanan kesehatan dasar seperti Puskesmas; Peningkatan manajemen pelayanan pengendalian PTM secara komprehensif (terutama promotif dan preventif) dan holistik; serta Peningkatkan ketersediaan sarana dan prasarana promotif-preventif, maupun sarana prasarana diagnostik dan pengobatan. Upaya Pencegahan dan Penanggulangan hipertensi dimulai dengan meningkatkan kesadaran masyarakat dan perubahan pola hidup ke arah yang lebih sehat (Kemenkes RI, 2017).

Pemerintah Kabupaten Badung terus berupaya untuk mencegah dan menanggulangi penyakit tdak menular (termasuk Hipertensi) di Kabupaten Badung. Salah satunya dengan menerbitkan Peraturan Bupati Badung Nomor 71 
Tahun 2014 tentang Pelaksanaan Kawasan Tanpa Rokok (KTR). Peraturan Bupati ini mengatur tentang tempat mempromosikan, mengiklankan, menjual dan/atau membeli rokok serta sangsi bagi yang melanggarnya (Bupati Badung, 2014).

Di samping itu, Dinas Kesehatan Kabupaten Badung juga melakukan revitalisasi Pos Pembinaan Terpadu (Posbindu) PTM. Posbindu PTM merupakan peran serta masyarakat dalam melakukan kegiatan deteksi dini dan pemantauan faktor risiko PTM Utama yang dilaksanakan secara terpadu, rutin, dan periodik. Kegiatan yang dilakukan untuk revitalisasi Posbindu antara lain; pelatihan SDM kesehatan, advokasi, pengadaan alat-alat deteksi dini PTM, pelaksanaan skrining faktor risiko PTM, surveilans epidemiologi dan sosialisasi pada Pos Pembinaan Terpadu (Posbindu) PTM dengan cara distribusi buku pedoman, distribusi leaflet, dan konseling. Selain Dinas Kesehatan, keterlibatan stakeholder dan peran serta masyarakat sangat dibutuhkan dalam menekan angka kesakitan dan kematian akibat Hipertensi di Kabupaten Badung.

\section{SIMPULAN DAN SARAN}

Berdasarkan hasil scoring menunjukan bahwa Hipertensi merupakan penyakit yang menduduko ranking pertama (prioritas) untuk ditangani di Kabupaten Badung dengan nilai score 63,8. Penyakit ini tergolong dalam kelompok penyakit tidak menular. Penyakit kedua yang prioritas untuk ditanggulangi adalah penyakit HIV/AIDS yang merupakan penyakit menular dengan nilai score 58,9, dan prioritas ketiga diduduki oleh penyakit Diabetes Melitus yang juga penyakit tidak menular dengan nilai score 58,7. Upaya Pemerintah Kabupaten Badung dalam pencegahan dan penanggulangan PTM (termasuk Hipertensi) adalah melalui penegakan Peraturan Bupati Badung Nomor 71 Tahun 2014 tentang Pelaksanaan Kawasan Tanpa Rokok (KTR) dan melakukan revitalisasi Pos Pembinaan Terpadu (Posbindu) PTM.

Adapun saran dalam penelitian ini: 1) Untuk meningkatkan layanan kesehatan pada Pos Pembinaan Terpadu (Posbindu) bagi kelompok risiko tinggi penyakit tidak menular (hipertensi), perlu diberikan pelatihan secara berkala kepada petugas pengelola program Posbindu puskesmas. 2) Bagi masyarakat dan ASN di lingkungan Pemerintah Kabupaten Badung yang melanggar Peraturan 
Daerah Kabupaten Badung Nomor 8 Tahun 2013 tentang Kawasan Tanpa Rokok (KTR) agar diberi sangsi tegas, terutama pelanggaran pada fasilitas umum seperti Rumah Sakit, Ruang Tunggu Terminal, lingkungan sekolah, dll. 3) Dinas Kesehatan serta sektor terkait agar melaksanakan sosialisasi kepada masyarakat tentang bahaya dan faktor risiko terjadinya hipertensi serta membuka layanan home-care bagi penderita hipertensi yang membutuhkan perawatan kesehatan di rumah.

\section{DAFTAR PUSTAKA}

Bupati Badung. (2014). Peraturan Bupati Badung Nomor 71 Tahun 2014 Tentang Pelaksanaan Kawasan Tanpa Rokok.

BAPPEDA Kab.Badung. (2016). Pembangunan Jangka Menengah Daerah (RPJMD) Semesta Berencana tahun 2016-2021.

.,Penyebab Penyakit Tidak Menular dan Pencegahan, Diunduh dari : https://doktersehat.com/penyebab-penyakit-tidak-menular-danpencegahan/ pada tanggal 1 April 2019.

Dinkes Kab.Badung. (2016). Rencana Strategis Dinas Kesehatan Kabupaten Badung Tahun 2016-2021.

Dinkes Kab.Badung. (2016). Sistem Pencatatan dan Pelaporan Terpadu Puskesmas (SP2TP).

Dinkes Kab. Tabanan. (2018). Profil Dinkes Kabupaten Tabanan Tahun 2019.

Haryuti, Saraswati, L. D., Udiyono, A., \& Adi, M. S. (2017). Gambaran tekanan darah dan indikator obesitas wanita usia subur di wilayah kerja Puskesmas Tlogosari Wetan Kota Semarang. Jurnal Kesehatan Masyarakat (JKM E-Journal), 5(2), 43-47.

Kemenkes, RI. (2019), Website Kementerian Kesehatan RI, diunduh dari http://www.depkes.go.id/article/view/18110200003/potret-sehatindonesia-dari-riskesdas-2018.html, pada tanggal 1 April 2019.

Kemenkes RI. (2019). Riset Kesehatan Dasar Tahun 2018.

Kemenkes RI. (2016). Pedoman Penyelenggaraan Program Indonesia Sehat Dengan Pendekatan Keluarga. 
Kemenkes RI. (2017). Hipertensi dan Penanganannya. diunduh dari http://www.p2ptm.kemkes.go.id/artikel-sehat/hipertensi-dan penanganannya. pada tanggal 1 April 2019.

Louisa, M., Sulistiyani, \& Joko, T. (2018). Hubungan penggunaan pestisida dengan kejadian hipertensi pada petani di Desa Gringsing Kecamatan Gringsing Kabupaten Batang. Jurnal Kesehatan Masyarakat (JKM EJournal), 6(1), 654-661

Marini, Devy. (2019). Faktor Risiko Hipertensi Pada Wanita Usia Subur (WUS) Di Wilayah Kerja Puskesmas Tamansari Kota Tasikmalaya Tahun 2019

Mardalena Ida. (2017). Dasar-Dasar Ilmu Gizi Dalam Keperawatan. Yogyakarta: Pustaka Baru Press

RS Daerah Mangusada. (2018). Laporan Kunjungan Pasien Rawat Jalan dan Rawat Inap.

Surya Darmawan. (2016). Administrasi Kesehatan Masyarakat. Jakarta: PT Raja Grafindo Persada 